\title{
Konsep Moderasi Dakwah dalam \\ M. Quraish Shihab Official Website
}

\section{The Modernization Concept of Dakwah in M. Quraish Shihab Official Website}

\author{
Mutaqin Alzamzami \\ UIN Sunan Kalijaga, Yogyakarta, Indonesia \\ Email: muttaqinalzamzami86@gmail.com \\ Artikel diterima 15 Juli 2019, diseleksi 23 Oktober 2019, \\ dan disetujui 10 Desember 2019
}

Abstrak: Pesan-pesan dakwah seharusnya disampaikan secara bijaksana dan kajiannya sudah sepatutnya berada di wilayah koridor ajaran Islam yang rahmatan lil 'alamin. Di era digital sekarang para da'i semestinya juga melibatkan media massa. M. Quraish Shihab telah memberikan perumpamaan bagaimana berdakwah dengan media massa. Melalui M. Quraish Shihab Official Website ia memberikan wawasan keislaman, dan melalui website tersebut penulis menemukan sebuah konsep moderasi dakwah yang memberikan pesan ajaran Islam damai dengan 4 bentuk penyampaian, yaitu, berbentuk artikel, quote, e-poster, dan video youtube.

Kata Kunci: Konsep, Moderasi, Dakwah, Website.

Abstract:Da'wah messages should be delivered wisely and the content of da'wah should be in the corridor area of Islamic teachings which are rahmatan lil amin alamin. In the digital era now the da'i should also carry out their da'wah by involving the mass media. M. Quraish Shihab has given parable of how to preach with the mass media. Through the M. Quraish Shihab Official Website he provides Islamic insights, and through the website the author has found a concept of M. Quraish Shihab's moderation da'wah. 
In his website, he gave messages of peaceful Islamic teachings in 4 forms, that is, in the form of articles, quotes, e-posters, and youtube videos.

Keywords: Concept, Moderation, Preaching, the Website.

\section{A. Pendahuluan}

\section{Latar Belakang Masalah}

Dalam mencapai tujuan dari sebuah aktivitas dakwah Islam yang moderat, dapat dilakukan dengan menitik tekankan pada ayat al-Qur'an, dalam hal ini berdasarkan pada Q. S. An-Nahl [16]: 125.

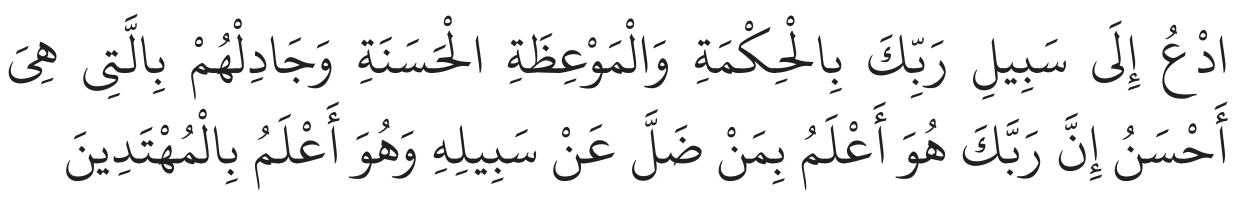

Artinya: "Serulah (manusia) kepada jalan Tuhan-mu dengan hikmah" dan pelajaran yang baik dan bantahlah mereka dengan cara yang baik. Sesungguhnya Tuhanmu Dialah yang lebih mengetahui tentang siapa yang tersesat dari jalanNya dan Dialah yang lebih mengetahui orang-orang yang mendapat petunjuk".

Sebenarnya ada persoalan dalam memahami paradigma dan etika dalam Islam. Q.S. an-Nahl [16]: 125 di atas perlu dihayati kembali maknanya. Ayat tersebut dapat dijadikan sebagai acuan untuk memahami tujuan, metode sekaligus etika dakwah. Artinya, dakwah tidak hanya cukup berbekal penampilan yang hanya membangkitkan emosi kolektif umat. Dakwah sejatinya dapat menyampaikan pesan-pesan universal agama sembari mengajak umat untuk memahami ajaran, tradisi dan konteks keumatan dengan baik, tepat dan benar. ${ }^{2}$

Tidak jarang juga terjadi dakwah yang dijadikan sebagai sarana dalam penyampaian ajaran Islam yang menimbulkan aksi-aksi intoleran, hal ini kerap kali disimbolkan dengan tindakan kekerasan dan anarkis. Kejadian semacam itu amat sayang jika terjadi, apalagi jika yang menjadi aktor ialah yang beragama Islam, sementara agama Islam sendiri adalah agama 
damai. Oleh sebab itu, agar eksistensi Islam sebagai agama rahmatan li al'àlamin tetap terjaga, maka sudah sepatutnya metode yang diterapkan dalam berdakwah harus dibahas secara terus-menerus dan tidak akan pernah usang dan membosankan. Karena menyampaikan al-amru bilma'ruf wannahhyu'anil-munkar menjadi kewajiban sesama umat muslim sampai akhir zaman. Dalam menerapkan metode dakwah yang benar tersebut, nantinya agar terealisasinya sebuah Islam moderat yang dapat menampilkan kembali jiwa dan raganya, serta tidak bertentangan dengan Pancasila dan semboyan Bhineka Tunggal Ika yang merupakan panduan bernegara di Indonesia, dan yang terpenting juga agar kehidupan beragama di Indonesia mampu hidup rukun dalam keanekaragaman.

Dalam menghadapi tantangan global, ada beberapa hal yang perlu diperhatikan seorang da'i. Da'i harus kritis dan analitis dalam menghadapi perkembangan dunia, misalnya media massa. Perkembangan dunia informasi di zaman sekarang sudah begitu mudah diakses siapa saja. Apabila da'i tidak mampu menguasai perkembangan dunia tersebut, maka jangan salahkan apabila yang memegang media massa jatuh ke tangan orang yang tidak bijak dan mereka dapat dengan mudah menguasai panggung dakwah melalui media massa tersebut dan menyebarkan ajaran Islam yang tidak rahmatan lil 'alamin.

Di era kontemporer seperti sekarang ini, banyak sekali cara yang dapat digunakan sebagai fasilitas dalam berdakwah, yang sangat menonjol di era sekarang ini ialah via digital. Digital merupakan bagian yang sangatberperan dan begitu praktis dalam melangsungkan kegiatan dakwah. Kemudahan berdakwah dengan via digital tersebut dapat dilihat dengan majunya teknologi yang dapat dengan mudah mengekspos berbagai tulisan maupun video yang bermuatan dakwah melalaui jejaring sosial. Kegiatan tersebut pada akhirnya tidak dapat terbendung lagi, karena bagi siapa saja yang memiliki fasilitas media tersebut, maka dia juga punya wewenang dan kesempatan dalam menyiarkan apa yang ingin dia sampaikan. Tulisan ini akan memberikan pemaparan tentang sebuah konsep dakwah Islam moderat dalam sebuah website M.Quraish Shihab.com. 


\section{Rumusan Masalah}

Dari pemaparan latar belakang masalah di atas, penulis dapat merumuskan beberapa masalah yang akan dikaji dalam penelitian ini, adapun rumusan masalah yang dimaksud ialah sebagaimana berikut:

1. Bagaimana bentuk-bentuk dakwah Islam yang dapat dilakukan pada masa sekarang?.

2. Bagaimana konsep moderasi dakwah dalam website M. Quraish Shihab.com?.

\section{Tujuan Penelitian}

1. Untuk mengetahui lebih rinci berbagai bentuk dakwah Islam.

2. Untuk mengetahui konsep moderasi dakwah dalam webasite M. Quraish Shihab.com.

Adapun kegunaan atau keuntungan yang ingin dicapai apabila penelitian ini berhasil dilakukan adalah:

1. Secara teoritis, hasil dari penelitian ini diharapkan mampu menjadi acuan atau sebagai bahan referensi bagi perkembangan kajian Ilmu keagamaan terkhusus dalam bidang dakwah.

2. Secara akademik, hasil dari kajian ini diharapkan mampu memberikan gambaran tentang konsep moderasi dakwah, dalam hal ini dispesifikasikan dalam bentuk website M. Quraish Shihab. com

\section{Kajian Pustaka}

Kajian pustaka dilakukan untuk mencapai tujuan penulisan yang telah disebutkan sebelumya, hal selanjutnya yang dilakukan adalah melakukan telaah pustaka. Telaah pustaka yang dilakukan bertujuan untuk mencari titik beda dari kajian-kajian terdahulu. Melalui kajian pustaka ini penulis hanya mengambil penelitian dari jurnal-jurnal yang telah terbit. 
Salah satu tulisan dari Rahmat Ramadhani dengan judul Rekonstruksi Aktivitas Dakwah melalui Media Masa, karyanya tersebut ia memfokuskan pada aktivitas dakwah melalui 4 media, yaitu media elektronik, Radio, Televisi, dan melalui media cetak (Printed Publications). Terdapat juga tulisan yang hanya memfokuskan pada satu media, yaitu karya dari Ibnu Hajar adapun judul tulisannya ialah Youtube sebagai Sarana Komunikasi Dakwah di Kota Makassar (Analisa Sosial Media), berbeda dengan tulisan Rahmad Ramadhani di atas, tulisan ini menganalisa tentang sebuah sarana komunikasi dakwah melalui media yang dalam hal ini memanfaatkan Youtube, dan penelitiannya juga hanya dikhususkan di satu daerah tepatnya di Ibu Kota Sulawesi Selatan.

Dakwah sebaiknya tanpa mengandung unsur diskriminasi, karena sebaiknya dalam berdakwah hendaknya mengajak dengan lemah lembut tanpa terselubung sifat kebencian. Melalui tulisan dari Eko Sumadi yang berjudul Dakwah dan Media Sosial: Menebar Kebaikan tanpa Diskriminasi, menurutnya aktivitas dakwah harus mengikuti perkembangan zaman atau biasa disebut dengan kontekstualisasi, dan isi dakwah diharuskan dengan cara yang arif dan bijaksana, tidak kontradiktif, diskriminatif, dan provokatif.

Media internet di era digitalisasi seperti sekarang ini, pastilah menuai sisi positif dannegatif bagi penggunanya. Sisi positif dan besar manfaatnya apabila digunakan sebagai sarana dakwah, tulisan salah satu dosen UIN Alauddin Makassar mengungkap peluang dan tantangan dakwah melalui media Internet, judul tulisannya ialah Pengembangan Strategi Dakwah melalui Media Internet (Peluang dan Tantangan). Menurutnya melaui internet dapat mendorong dinamika Islam dan memperkokoh ketahanan nilai-nilai Islam dalam aktivitas dakwah yang akomodatif, sementara tantangan yang besar juga bakal dihadapi karena perubahan zaman yang setiap kali memunculkan pertanyaan dan kajian baru, dan mengingat beragamnya kebutuhan maupun kepentingan manusia yang kini cenderung lebih kritis. 
Dari pemaparan telaah pustaka tersebut, juga dari sejauh pembacaan dan sepengetahuan penulis belum ada yang membahas dan menelitisecara mendalam mengenai konspep moderasi dakwah yang memfokuskan pada sebuah website terutama di M. Quraish Shihab Official website.

\section{Metodologi Penelitian}

Tahap pertama yang dilakukan dalam penulisan ini ialah pengumpulan data. Penulis melakukan pencarian dari berbagai suber-sumber data yang mempunyai relevansi dengan tema penelitian ini. Adapun data yang digunakan berasal dari sumber data primer dan skunder. Data yang telah terkumpul kemudian dianalisa (content analysis) secara kualitatif yang kemudian dideskripsikan sehingga dapat diambil kesimpulan.

\section{B. Hasil dan Pembahasan}

\section{Biografi M. Quraish Shihab}

Sejak kecil, M. Quraish Shihab telah ditanamkan kedua orang tuanya pemahaman dan pengamalan agama. Pendidikan dasarnya diselesaikan di Makassar dan dilanjutkan pada jenjang menengahnya di kota Malang, Jawa Timur sambil nyantri di Pesantren Dar al-Hadits al-Fiqhiyyah. Setudinya pada jenjang tersebut belum selesai, ia berangkat ke Mesir pada tahun 1958 bertepatan usianya mencapai 14 tahun untuk melanjutkan studi di Universitas al-Azhar. Di Universitas al-Azhar, Kairo, Mesir, M. Quraish Shihab diterima di kelas II Tsanawiyah (setingkat SLTP). Pada tahun 1967, ia meraih gelar Lc (S-1) pada fakultas Ushuluddin Jurusan Tafsir dan Hadits. Kemudian ia melanjutkan pendidikannya di fakultas yang sama, dan pada 1969 meraih gelar MA. Ia berhasil meraih gelar doktor pada tahun 1982, gelar doktornya tersebut ditempuhnya di Universitas yang sama yaitu di al-Azhar. ${ }^{3}$

Setelah kembalinya ke Indonesia, M. Quraish Shihab menjadi sosok serjana muslim kontemporer Indonesia yang menjalani karir akademik dan sosial kemasyarakatan dan pemerintahan, sukup sukses. Sejak tahun 
1984, ia ditugaskan di Fakultas Ushuluddin dan Fakultas Pascasarjana IAIN Syarif Hidayatullah. Dalam bidang sosial kemasyarakatan, ia pernah dipercaya selaku pembantu rektor, rektor IAIN (kini UIN) Syarif Hidayatullah (1992-1998. ${ }^{4}$

Kiprahnya tak terbatas di lapangan akademis. Beliau menjabat sebagai Ketua Majelis Ulama Indonesia (Pusat) 1985-1998; anggota MPR-RI 19821987 dan 1987-2002; dan pada 1998, dipercaya menjadi Menteri Agama RI. Beliau juga dikenal sebagai penulis yang sangat produktif. Lebih dari 20 buku telah lahir dari tangannya. Di antaranya yang paling legendaris "Membumikan Al-Qur'ab”, "Lentera Hati”, "Wawasan Al-Qur'an” dan "Tafsir Al-Mishbah". Sosoknya juga sering tampil di berbagai media untuk memberikan siraman ruhani dan intelektual. Aktivitas utamanya sekarang adalah Dosen (Guru Besar) Pascasarjana Universitas Islam Negeri (UIN) Jakarta dan Direktur Pusat Studi Al-Qur'an (PSQ) Jakarta. ${ }^{5}$

Di sela-sela pelbagai kesibukannya, ia masih sempat terlibat dalam pelbagai kegiatan ilmiah di dalam maupun luar negara, dan aktif dalam kegiatan tulis-menulis. Beberapa buku yang dihasilkannya ialah: Tafsir AlManar, Keistimewaan dan Kelemahannya (Ujung Pandang: IAIN Alauddin, 1984), Filsafat Hukum Islam (Jakarta: Departemen Agama, 1987), Mahkota Tuntunan Ilahi (Tafsir Fungsi dan Peran Wahyu dalam Kehidupan Masyarakat (Bandung: Mizan, 1992), Lentera Hati Kisah dan Hikmah Kehidupan (Bandung: Mizan, 1994), Wawasan AL-Qur'an (Bandung: Mizan, 1996), Hidangan Ilahi Ayat-ayat Tahlil (Jakarta: Lentera Hati, 1997), Yang Tersembunyi (Jakarta: Lentera Hati, 1999), Tafsir Al-Misbah, Pesan Kesan dan Keserasian AL-Qur'an (Jakarta: Lentera Hati, 2000), dan beberapa buku lain. ${ }^{6}$

Para mahasiswa Indonesia tingkat sarjana Pada Institut Studi-studi Islam Universitas MCGill menyatakan bahwa terbitan-terbitan M. Quraish Shihab meletakkan standar baru bagi studi-studi al-Qur'an yang digunakan oleh penduduk muslim awam. Dan mereka jugalah yang serius memunculkan masalh pengikutsertaan analisis terhafap 
tulisan-tulisan M. Quraish Shihab dalam edisi-edisi mendatang studi Howard M. Federspiel. Ketika Howard M. Federspiel menelaah salah satu buku M. Quraish Shihab yang berjudul "Membumikan Al-Qur'an", ia menyatakan bahwa ia harus sepakat bahwa M. Quraish Shihab layak untuk didiskusikan dalam edisi mendatang bukunya "Kajian Al-Quran di Indonesia: Dari Mahmud Yunus hingga Quraish Shihab".7

\section{Fenomena Konflik}

Dalam dua tiga tahun terakhir di penghujung tahun 2000 ini terjadi lagi beberapa konflik antara kalangan Muslim dan Kristen di beberapa daerah di Tanah Air mengakibatkan munculnya serangkaian gangguan terhadap kerukunan dan keharmonisan dalam beragama ${ }^{8}$. Konflikkonflik dalam ruang lingkup Indonesia dapat disebut misalnya, aksi pembakaran beberapa gereja di Ujung Pandang (Makassar) pada tahun 1967 oleh kalangan pemuda muslim menjadi bukti plus sebagai kenangan kelam bagi citra Agama Islam. Tidak berhenti disana, counter yang dilakukan oleh Umat Kristiani yaitu pembakaran masjid di Sulawesi Utara dan Ambon membuat suasana keberagamaan pada saat itu semakin bergejolak dan suram. Indonesia benar-benar dalam keadaan krisis keberagamaaan. Sejak jatuhnya pemerintahan Presiden Soeharto pada 1998, konflik dan kekerasan yang berbau SARA kembali muncul di Indonesia. Sebut saja kasus Ketapang-Jakarta ${ }^{10}$, Kupang (Nusa Tenggara Timur).

Tindakan-tindakan intoleran yang terjadi di bumi pertiwi ini sebenarnya menimbulkan gangguan yang sangat serius terhadap sendisendi kerukunan sosial dan tatanan kerukunan antarumat beragama di Indonesia. Karena situasi konflik belum mendapat jaminan bakal tidak akan muncul lagi, maka sudah selayaknya seluruh masyarakat Indonesia menaruh perhatian secara serius dengan berperan aktif dalam menjaga kerukunan antarumat beragama. Dari beberapa kasus tersebut mengindikasikan bahwa Indonesia sangat rentan atas terjadinya tindak intoleran baik dulu, pascakemerdekaan, bahkan hingga sekarang pun masih kerap terjadi. 
Tentang keragaman dan keberbedaan (kemajemukan) ini, Tuhan pun telah menggambarkan pada diri manusia dengan lima jari tangan yang saling berbeda, Bedjo Sujanto menyebutnya sebagai "Falsafah Lima Jari." Menurutnya, jika Tuhan berkehendak ${ }^{11}$, tidaklah sulit untuk membuat jari kita lima-limanya menjadi satu bentuk. Namun, fitrah keragaman jari itupun diciptakan, dengan masing-masing ciri, fungsi dan peran dari tiap-tiap jari. Apabila kelima jari itu disatukan (bersatu), maka akan terbangun suatu kekuatan yang sangat luar biasa.

\section{Konsep Islam dalam Meredamkan Disintegrasi}

Dalam kitab suci al-Qur'an keberagaman atau kemajemukan merupakan suatu fitrah dari Allah Swt. Sebagai Sang Pencipta, sebagaimana firman Allah Swt. mengenai pengakuan pluralisme tepatnya pada Q.S. al-Hujurāt [49]: 13).

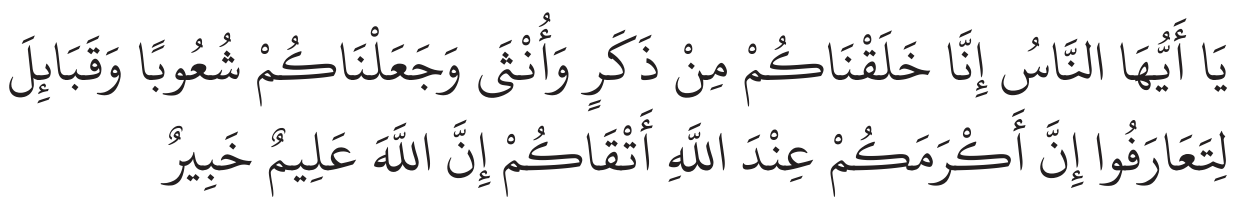

"Hai manusia, sesungguhnya Kami menciptakan kamu dari seorang laki-laki dan seorang perempuan dan menjadikan kamu berbangsa-bangsa dan bersukusuku supaya kamu saling kenal-mengenal, sesungguhnya orang yang paling mulia di antara kamu di sisi Allah ialah orang yang paling bertaqwa di antara kamu. Sesungguhnya Allah Maha Mengetahui lagi Maha Mengenal."

Untuk menjadi muslim toleran, seseorang harus menjadi pluralitas tanpa harus menjadi relativis. Artinya, muslim toleran dan pluralis adalah seseorang yang mengakui dan menghargai pluralitas adalah seseorang yang mengakui dan menghargai pluralitas pemahaman dan keyakinan tanpa harus membenarkan semuanya. Dalam Islam, pluralitas merupakan keniscayaan sebagaimana dalam firman Allah. "Jika Tuhamu menghendaki, tentu Dia menjadikan manusia umat yang satu, tetapi mereka senantiasa berselisih pendapat." Q.S. Hūd [11]: 119. Allah memberikan aturan dan jalan yang terang kepada masing-masing umat beragama. Sekiranya Allah menghendaki, niscaya umat manusia akan dijadikan- 
Nya satu umat saja, tetapi Allah hendak menguji umat manusia terhadap pemberian-Nya, maka umat manusia diperintahkan berlomba-lomba dalam berbuat kebajikan (Q.S. al-Mā'idah [5]: 48). Firman Allah ini mengafirmasi pluralitas sebagai sebuah keniscayaan yang tidak bisa terbantahkan. Maka, pengakuan terhadap keberagaman adalah sikap proposional yang tidak bisa ditawar-tawar lagi. ${ }^{12}$

Dalam Q.S. al-Hajj [22]: 20, adapun bunyi ayatnya ialah sebagaimana berikut:

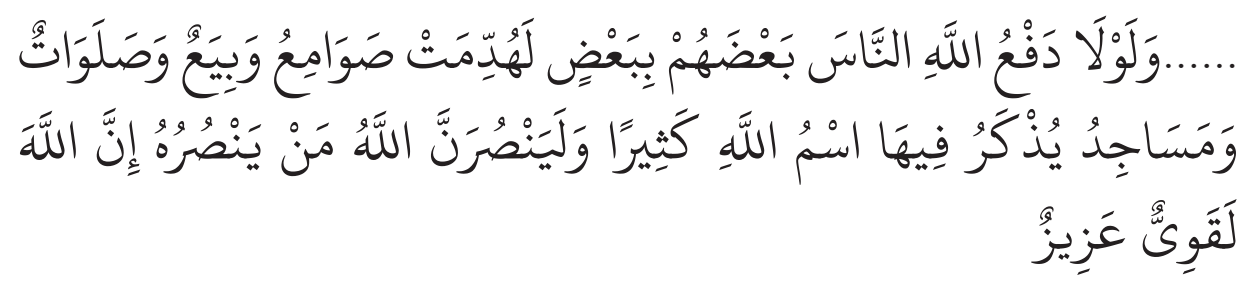

Artinya: ...... Dan sekiranya Allah tiada menolak (keganasan) sebagian manusia dengan sebagian yang lain, tentulah telah dirobohkan biara-biara Nasrani, gereja-gereja, rumah-rumah ibadat orang Yahudi dan masjid- masjid, yang di dalamnya banyak disebut nama Allah. Sesungguhnya Allah pasti menolong orang yang menolong (agama)-Nya. Sesungguhnya Allah benarbenar Maha Kuat lagi Maha Perkasa.

Di sini ayat al-Qur'an dengan tegas mengatakan bahwa nama Allah tidak hanya disebut terbatas di masjid, tetapi juga di biara (shawāmi'), gereja (biya'), sinagog (shalawāt). Artinya, tak seorang pun punyahakuntuk menghalangi pihak lain dalam menjalankan ibadah menurut agama dan kepercayaannya masing-masing. Dengan demikian, perusakan terhadap tempat-tepat ibadah dari agama yang beragam sama artinya dengan pembangkangan terhadap ketentuan Allah dalam al-Qur'an. ${ }^{13}$

Relasi sosial antarumat beragama semakin sensitif akibat agama yang satu menafikan yang lain. Ketika masing-masing agama menjalankan misi truth claim-nya, maka yang terjadi adalah benturan antar-truth claim. Benturan tersebut tak ada titik akhir karena di antara mereka tidak ada yang mampu membuktikan secara empiris mengingat kebenaran agama 
adalah kebenaran keyakinan. Hal yang dapat menghindari benturan tersebut adalah rasa toleran dan kedewasaan dalam membangun relasi antarumat beragama. ${ }^{14}$

Al-Qur'an kemudian juga menegaskan tentang kebebasan memilih keyakinan ini dalam Q.S al-Baqarah [2]: 256:

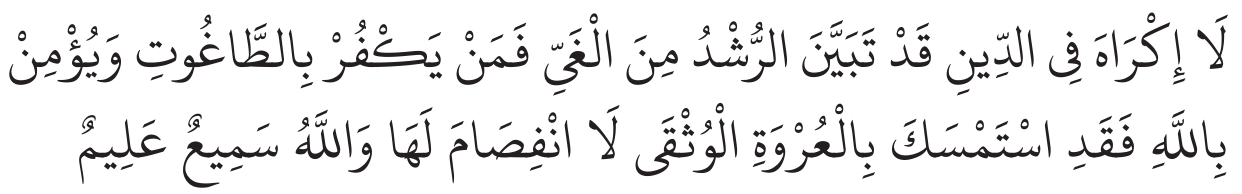

"Tidak boleh ada paksaan dalam agama. Sungguh telah nyata (berbeda) kebenaran dan kesesatan. Karena itu, barangsiapa yang ingkar kepada thāghūt dan beriman kepada Allah, sesumgguhmya ia telah berpegang kepada tali yang amat kuat yang tak akan putus, Allah Maha Mendengar dan Mengetahui".

Abu Muslim dan al-Qaffal berpendapat, ayat ini hendak menegaskan bahwa keimanan didasarkan atas suatu pilihan dengan kesadaran dan bukan atas suatu tekanan. ${ }^{15}$ Menurut Muhammad Nawawi al-Jāwi, ayat ini menyatakan bahwa pemaksaan untuk masuk dalam suatu agama tak dibenarkan. ${ }^{16}$

Dari ayat di atas dapat dikatakan bahwa dalam hal penyebaran agama, harus memperhatikan aspek toleransi antar-umat beragama yang beragam (pluralis dalam hal keimanan) dan multikultural dalam hal budaya yang dianut dan berkembang. ${ }^{17}$ Dakwah agama tidak bisa dilakukan secara sewenang-wenang sehingga menyinggung umat agama lain yang berbeda dengan keyakinan kita. Kita hanya diperbolehkan menyebarkan agama tanpa menyinggung dan menghakimi umat agama yang lain, yang berbeda dengan kita sebab Tuhan sendiri telah menakdirkan ada banyak umat beragama, semuanya agar saling beriman dan tolong menolong. ${ }^{18}$

Dalam ranah sosial, kita sebagai umat beriman harus saling membantu dengan yang berbeda agama. Dalam ranah teologis kita harus menghormati yang berbeda keyakinan, sebab Tuhan telah menghadirkan 
Rasul-Rasul-Nya dan Kitab-Nya dalam setiap periode kenabian dan umat manusia. Perlombaan dalam kebajikan itulah yang diharapkan dapat membawa kebaikan antar umat beragama di muka bumi. Ayat ini, dengan demikian, secara teologis dapat dikatakan sebagai landasan teologis dan sosiologis untuk terjadinya penghargaan dan mengakui adanya multikulturalisme dalam Islam terhadap agama lain. ${ }^{19}$

Beragama secara beradab sama dengan beragama secara jujur, tulus, dan lapang dada. Dengan sikap lapang dalam hal kesediaan kita mengakui hak orang lain untuk berpendirian bahwa agama yang dipeluknya adalah yang paling benar, sekalipun kita perlu tidak menyetujuinya. Pada waktu yang sama, orang lain juga harus menghormati pendirian orang Islam yang mengatakan bahwa Islam adalah agama yang paling benar. Ungkapan "paling benar" di sini harus dikembalikan kepada kepercayaan pemeluknya masing-masing. Adalah sebuah sikap tak beradab, jika seseorang berkata: "Agama kamilah yang paling benar, agama anda sarat dengan mitos dan kepercayaan karut". Pernyataan semacam ini jelas tidak berkebudayaan..$^{20}$

Ajaran tentang toleransi di dalam dakwah semestinya mendapatkan perhatian, khususnya oleh para da'i dan akademisi. Para da'i dan cerdik cendekia diharapkan dapat membangun iklim toleransi di lingkungan masing-masing, baik di masjid, madrasah, kampus, kantor maupun lembaga kekuasaan politik. Dakwa yang merupakan panggung pencerahan dan pemberdayaan masyarakat diharapkan dapat memberikan alternatif bagi terciptanya suasana yang kondusif untuk membangun toleransi di tengah keragaman. Dengan demikian, toleransi harus menjadi tindakan nyata yang dapat membentuk kesadaran kolektif. Sejatinya, dakwah tidak dalam rangka menafikan wahyu keragaman, melainkan justru meneguhkan kebersamaan dalam bingkai kemanusiaan. ${ }^{21}$ 


\section{Konsep Moderasi Dakwah dalam Website M. Quraish Shihab Official Website}

\section{a. Tampilan Website}

Tampilan M. Quraish Shihab Official Website memiliki variasi yang menarik dalam mentransformasikan wawasan keagaamaan. Jika melihat pada tampilan awal website tersebut, maka yang terlihat adalah 5 menu utama pada bagian atas website, yaitu menu Home, Blog, Work, Books, dan Contact. Pada menu Blog, terbagi menjadi 6 bagian, yaitu article, audio, e-poster, events, quote, dan video. Sedangkan pada menu Books, terbagi menjadi dua bagian, yaitu print books dan e-books. Pada menu utama contact di dalamnya terdapat penjelasan mengenai website tersebut yang membuka layanan bagi siapa saja yang ingin bertanya seputar keislaman, dan pertanyaan yang telah dijawab diarsipkan dalam Alifmaqz.com. tidak hanya itu, pada menu contact juga menyediakan buku karya M. Quraish Shihab. Dan untuk seputar hal lainnya, siapa saja bisa menghubungi Pusat Studi al-Qur'an dengan alamat email info@psq. or.id.

Tampilan yang disajikan M. Quraish Shihab Official Website menurut hemat penulis tersistemasi dalam menyajikan berbagai wawasan keagamaan, hal tersebut dapat dilihat dengan adanya menu categories. Dalam menu categories tersebut, terdapat 41 sub tema kajian. Tampilan menarik lainnya, dalam website tersebut juga menampilkan calender serta terdapat menu recommended.

\section{b. Berbentuk Quote}

Dalam menyajikan materi, dalam website tersebut terdiri dalam berbagai bentuk tampilan, salah satunya berbentuk quote. Kolom quote menjadi satu bagian tersendiri dalam website tersebut, sampai selesainya penelitian ini quote yang telah tersajikan sudah mencapai tiga laman dengan jumlah gambar quote telah mencapai 23 gambar, dan setiap laman terisi penuh dengan 10 gambar quote. Dari 23 gambar 
quote terseut, hemat penulis terdapat 5 quote yang menggambarkan kelembutan ajaran Islam.

Nabi Muhammad saw. tidak meminta balasan apa pun dari umat manusia. Yang beliau harapkan hanyalah perlakuan baik, bukan permusuhan, karena adanya hubungan kekerabatan/kemanusiaan antara sesama. Di samping itu, Rasul saw. tidak mengharapkan imbalan dari penyampaian misi suci ini, kecuali agar manusia menyambut seruan beliau serta mencintai Allah swt. dan Rasul-Nya pada saat mendekatkan diri kepada-Nya dengan melakukan perbuatan baik.

\section{KARENA POSISI YANG BAIK ADALAH POSISI TENGAH. MAKA ISLAM MENGANJURKAN DAN MENGAJARKAN WASHATHIYAH (MODERASI) DALAM ANEKA ASPEK AJARANNYA.}

Islam adalah agama damai yang mencintai kemanusiaan. Ia membawa rahmat dan kedamaian bagi seluruh alam. Bahkan, walau dalam keadaan bermusuhan, Islam tetap memerintahkan kejujuran tingkah laku dan perlakuan yang adil.

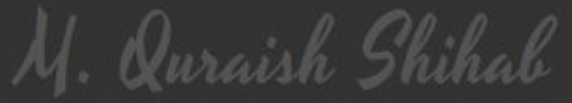


Peperangan hanya dibenarkan terhadap mereka yang sedang melakukan agresi, bukan terhadap yang tidak menyerang

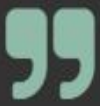
kaum Muslim, bahkan sementara ulama menyatakan bahwa yang diduga akan menyerang tidak dapat dibenarkan untuk menyerangnya sebelum jelas bahwa memang mereka telah benar-benar siap untuk menyerang.

Tidak dibenarkan berselisih dalam prinsip-prinsip ajaran agama. Tidak wajar juga masing-masing berkeras memaksakan pendapatnya dan menilai pendapat lain salah.

Di Hari Kemudian, Allah swt. akan memutuskan yang benar tentang prinsip-prinsip ajaran. Sedangkan dalam rincian ajaran, Allah swt. akan menyampaikan tentang kebenaran semua pihak selama masih dalam koridor yang dibenarkanNya sekaligus akan menyampaikan kesalahan pihak bertengkar dan bersitegang.

\section{c. Berbentuk E-Poster}

Selain quote, E-Poster juga masuk dalam bagian tampilan di website tersebut. Tampilan gambar poster tidak jauh berbeda dengan tampilan quote, bahkan penulis menemukan satu gambar yang di website tersebut masuk dalam kategori E-Poster dan quote. Jumlah E-Poster sampai sekarang sudah mencapai 5 laman, dan setiap laman memiliki batas maksimum gambar yang sama dengan quote, yaitu 10 gambar. Di laman terakhir E-Poster tersebut sudah terisi 3 gambar, sehingga jumlah gambar E-Poster sekarang ini sudah mencapai 43 gambar. Dari pengamatan penulis, secara keseluruhan yang telah terekspose dalam E-Poster tersebut, terdapat 9 gambar pesan-pesan yang berhubungan dengan agama yang merupakan cinta kasih, kedamaian, kebersamaan dan cinta tanah air. 

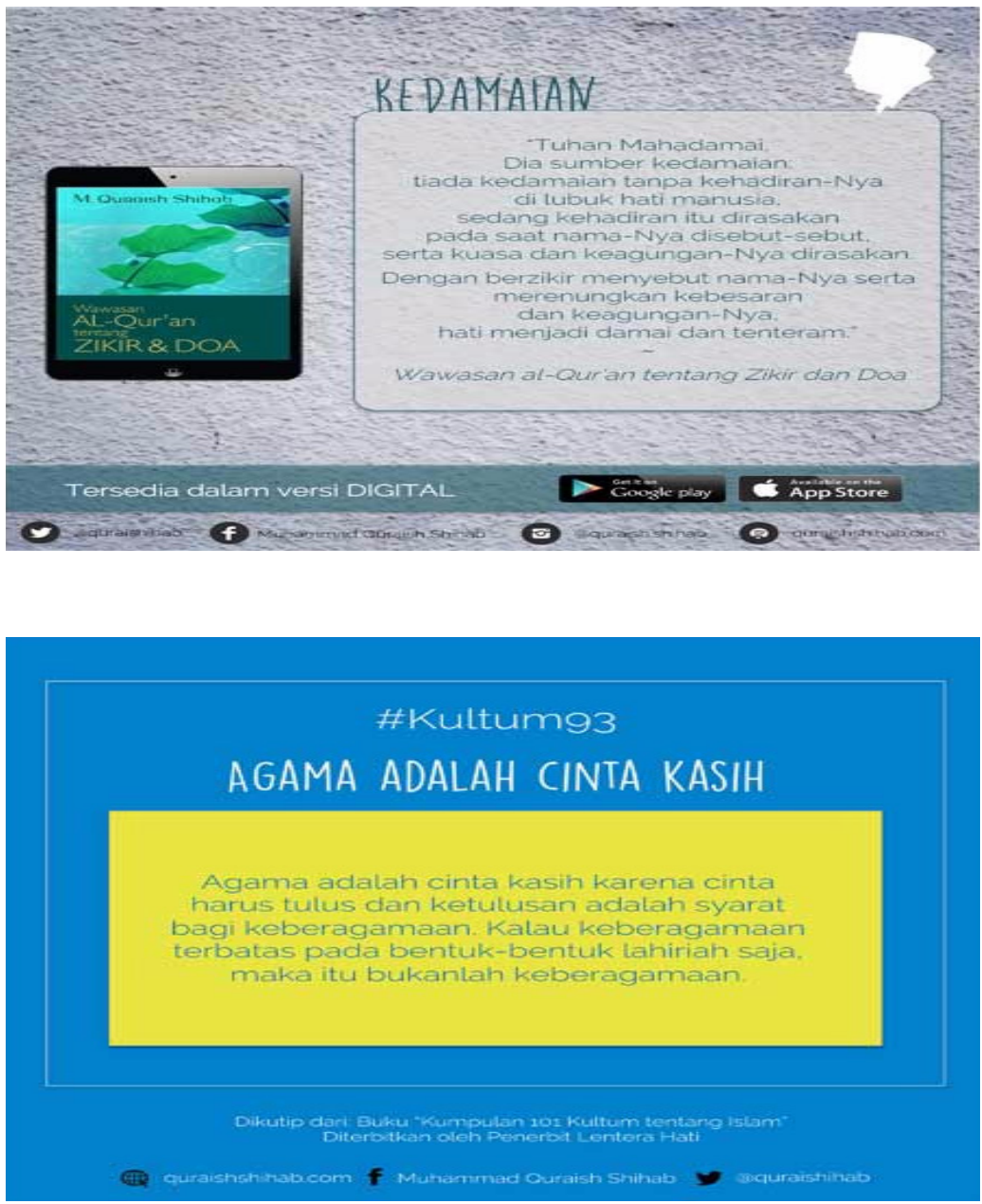

ADA DUA MACAM KESELAMATAN/KEDAMAIAN YANG DIAJARKAN AGAMA. YANG PERTAMA BERSIFAT PASIF DAN KEDUA AKTIF. ISLAM MEMERINTAHKAN MEMBERI KEDAMAIAN TERHADAP ORANG-ORANG PICIK YANG BERLAKU BURUK TERHADAP ANDA. 


\section{d. Berbentuk Video Youtube}

Perkembangan teknologi seperti sekarang ini, juga berdampak positif bagi pendakwah maupun mad'u, karena mampu membuka akses dalam menyalurkan pesan-pesan dakwah, maupun pendidikan secara umum dapat dengan mudah terealisasikan. Metode pembelajaran sekarang ini, tidak hanya sebatas membaca dan menulis saja, namun terdapat metode visual. Masa-masa sekarang ini, youtube menjadi akses yang sering dinikmati khayalak umum, tak kenal batas usia baik orang tua maupun anak-anak dapat dengan mudah menonton apa yang telah tersedia di Youtube. Bahkan menariknya, setiap orang tidak hanya mampu sekedar menikmati video di channel-channel tertentu, melainkan siapa saja dengan ketentuan yang relatif ringan mampu memberikan edukasi atau apa saja yang bisa diekspose di channel pribadi.

Didalam M.Quraish Shihab Official Website tersebut, juga memberikan edukasi melalui video yang tersalurkan melalui channel youtube. Di website tersebut telah menampilkan 11 laman, dan setiap laman menampung maksimal 10 video, sehingga sekarang ini jumlah video yang telah masuk dalam website tersebut mencapai 109 video, dan setiap video berdurasi di antara 4 sampai 15 menit. Dapat dikatakan metode dakwah via video youtube cukup efisien, mengingat hampir setiap pengguna android mengakses youtube, sehingga konten keagamaan dalam kajian dakwah tersebut tidak hanya sebatas diterima oleh jama'ah yang hadir dalam pengajian, namun ajaran yang disampaikan da'i juga mampu diterima pengguna youtube di manapun ia tinggal, selama ia menonton channel dakwah tersebut.

Dalam website tersebut penulis menemukan satu video dengan durasi 4.03 menit yang membahas mengapa manusia terdiri dari berbagai agama, sedangkan dalam al-Qur'an Allah menyatakan secara eksplisit dalam potongan Q.S. al-Mā'idah [3]: 48

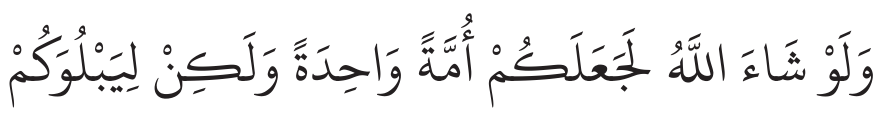


"Sekiranya Allah menghendaki, niscaya kamu dijadikan-Nya satu umat (saja), tetapi Allah hendak menguji kamu"

Bahwa jika Allah berkehendak niscaya manusia akan dijadikan-Nya satu umat (saja). Menurut M. Quraish Shihab Tuhan tidak menghendaki kita semua memeluk agama yang sama, karena ingin memberikan manusia kebebasan memilih. Karenanya kita diberi kemampuan memilih dan memilah. dan ia juga menyinggung apa yang terdapat dalam Q.S. alKāfirūn [109]: 1-5.

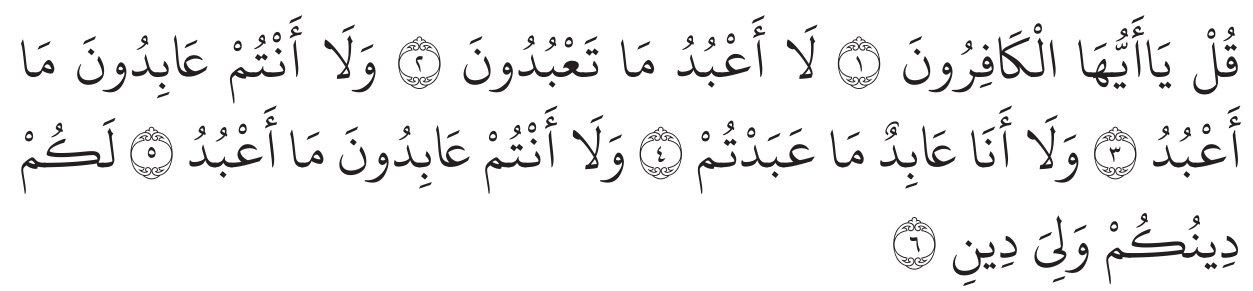

"1. Katakanlah: "Hai orang-orang kafir, 2. Aku tidak akan menyembah apa yang kamu sembah, 3. Dan kamu bukan penyembah Tuhan yang aku sembah, 4. Dan aku tidak pernah menjadi penyembah apa yang kamu sembah, 5. dan kamu tidak pernah (pula) menjadi penyembah Tuhan yang aku sembah, 6. Untukmu agamamu, dan untukkulah, agamaku."

Dan ia juga menegaskan bahwa Tuhan enggan memaksa manusia untuk menganut agama tertentu, oleh karenanya maka kita harus bersikap toleran, dengan tidak mengusik dan menjelek-jelekkan agama orang lain, yang terpenting pesan beliau ialah keberagaman dalam beragama tidak menghalangi kita untuk hidup damai dan bekerja sama untuk hal-hal kebaikan.

\section{e. Berbentuk Artikel}

Arikel yang telah dimuat dalam website Muhammad Quraish Shihab Official Website sebanyak 5 laman yang terdiri dari 44 artikel. Terdapat satu artikel yang membahas mengenai dakwah dengan judul Dakwah yang Bijak. M. Quraish Shihab memuali tulisannya dengan terlebih dahulu menekankan pada sebuah arti dakwah, menurutnya dakwah adalah ajakan kepada kebaikan dengan cara yang terbaik. Dapat diartikan juga 
dengan upaya memberi hidayah yakni petunjuk. Berdakwah semestinya disampaikan dengan lemah lembut, ia menukil ayat al-Qur'an tepatnya pada penggalan ayat dalam Q.S. Āli Imran [3]: 159:

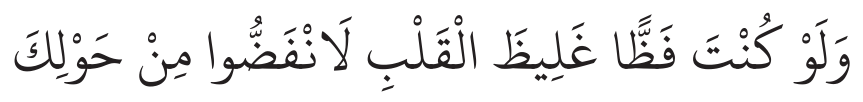

"Sekiranya engkau berucap kasar lagi berhati keras, tentulah mereka menjauhkan diri dari sekelilingmu"

Da'i disebut juga mubaligh, disebut mubaligh karena ia mampu menyusun kata sehingga mampu menyampaikan pesannya dengan baik. Di dalam al-Qur'an kata balighā terdapat dalam Q.S. an-Nisā' [4]: 63.

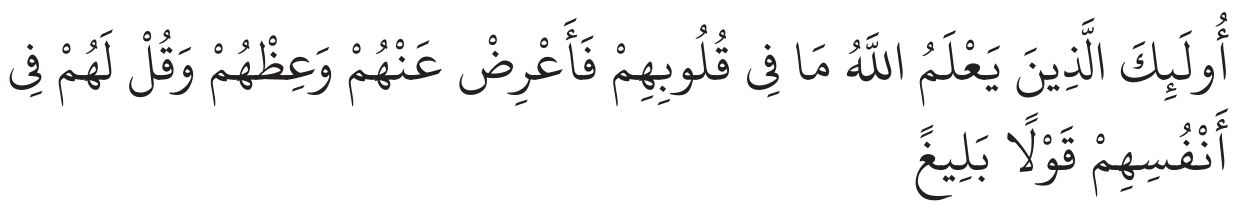

"Mereka itu adalah orang-orang yang Allah mengetahui apa yang di dalam hati mereka. Karena itu berpalinglah kamu dari mereka, dan berilah mereka pelajaran, dan katakanlah kepada mereka perkataan yang berbekas pada jiwa mereka."

Seorang da'i menurut M. Quraish Shihab tidak hanya pandai dalam menyampaikan hal-hal yang benar dengan dibungkus dalam susunan kalimat yang baik, melainkan juga harus mempertimbangkan waktu yang tepat, hal tersebut dapat dilihat pada Q.S. al-Ahzāb [33]: 70,

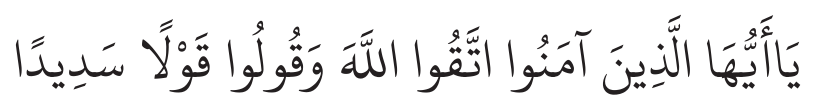

"Hai orang-orang yang beriman, bertakwalah kamu kepada Allah dan katakanlah perkataan yang benar"

Kata sadīdā pada ayat di atas mensifatkan informasi yang baik, kata tersebut juga mengandung makna meruntuhkan kemudian memperbaikinya. Contohnya apabila kita mengkritik semestinya disampaikan dengan lemah lembut dan disertai dengan usul perbaikan yang membangun dan kata sadìdā juga berarti tepat. Sehingga, dalam berdakwah seorang 
da'i harus mempertimbangkan banyak hal. Salah satunya ialah ucapan yang lemah lembut, agar tidak menyinggung perasaan orang lain dan menimbulkan amarah. Perkataan lemah lembut tersebut juga terdapat dalam Q.S. Taha [20]: 44:

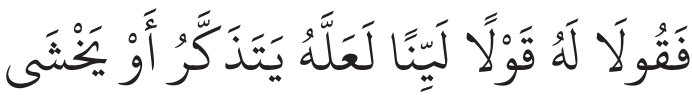

"Maka berbicaralah kamu berdua kepadanya dengan kata-kata yang lemah lembut, mudah-mudahan ia ingat atau takut."

Dalam website M. Quraish Shihab Official Website menyediakan 41 kategori, satu di antaranya khusus membahas perdamaian. Di dalam kategori perdamaian tersebut terdapat 2 laman yang terdiri dari 5 judul artikel. Pertama, "Pertemuan Grand Syaikh al-Azhar dan Majelis Hukama' al-Muslimin di Jakarta", Kedua dan Ketiga, "Timur dan Barat di Era Globalisasi I dan bagian II”, Keempat, “Terjemahan Naskah Janji Rasulullah Muhammad Saw. dengan Penganut Agama Kristen, Kelima, "selamat Natal".

\section{Penutup}

Bentuk dakwah Islam yang berdasarkan al-Qur'an dan Hadits Nabi Saw. dapat dijalankan dengan tiga bentuk. Pertama, dakwah bil-Hal, Kedua, dakwah bil-Lisan, dan Ketiga, dakwah bil-kitabah. Kesemua bentuk dakwah tersebut dapat disalurkan melalui media massa sebagai mana canggingnya perkembangan zaman saat ini. Sekarang kita menghadapi zaman serba digital, oleh sebab itu aktivitas dakwah mau tidak mau juga harus terjun melalui dunia digital. Perkembangan dunia informasi di zaman sekarang sudah begitu mudah diakses siapa saja, termasuk para da'i agar dapat menyebar kebaikan dan wawasan keislaman melalui media tersebut.

M. Quraish Shihab melalui website M. Quraish Shihab Official juga menjalankan aktivitas dakwah dengan mengikuti perkembangan zaman yang ada saat ini. Ia masih aktif berdakwah melalui oral seperti yang 
biasa dilakukan para da'i pada umumnya, namun ia juga tidak monoton, melainkan juga mengikuti perkembangan zaman, sehingga berdakwah secara lisan tetap terus dilakukannya dengan mengekspose dakwahnya tersebut dalam media massa dengan dikemas secara menarik dalam youtube. Kegemarannya menulis juga dimanfaatkanya sebagai ajang dakwah, tidak hanya melalui karya buku sebagai saran edukasi dan pesan dakwah, ia juga menulis di websitenya tersebut dalam bentuk quote, e-poster dan artikel.

Dalam websitenya, M. Quraish Shihab ikut andil dalam menyeuarakan pesan damai yang semestinya tetap dijaga oleh setiap agama terutama dari kalangan muslim. Cukup menarik apabila kita melihat tampilan websitenya tersebut, ia dalam menyuarakan pesan damai merasa tidak cukup jika hanya melalui pesan secara lisan, ia juga melalui tulisan dan mengemasnya dengan tampilan gambar yang menarik sehingga dapat dengan cepat dicerna dan nikmati khyalak umum. 


\section{Daftar Pustaka}

Al-Jawi, Muhammad Nawawi. Marāh Labīd. Beirut: Dar al-Kutub alIlmiyah. 1997.

Al-Razi, Fakhr al-Din. Mafātih al-Ghaib, CD ROM Al-Maktabah AsSyamilah Versi 3.48. Beirut: Dar Ihya' at-Turats. 1999.

Ar-Rifa'i, Muhammad Nasib. Ringkasan Tafsir Ibnu Katsir. Jakarta: Gema Insani. 2000.

Federspiel, Howard M. Kajian Al-Qur'an di Indonesia; dari Muhammad Yunus hingga Quraish Shihab, terj. Tajul Arifin. Bandung: Mizan. 1996.

Gusmian, Islah. Khazanah Tafsir Indonesia dari Hermeneutika hingga Ideologi. Jakarta: Teraju. 2003.

Isma'il, Faisal. Republik Bhinneka Tunggal Ika. Jakarta: Badan Litbang dan Diklat Kementrian Agama. 2012.

Maarif, Ahmad Syafii. Dalam Fikih Kebinekaan Pandangan Islam Indonesia tentang Umat, Kewargaan, dan Kepemimpinan Non-Muslim. Bandung: Mizan. 2015.

Masduqi, Irwan. Berislam Secara Toleran: Teologi Kerukunan Umat Beragama, Bandung: Mizan. 2011.

Misrawi, Zuhairi. Al-Qur'an Kitab Toleransi: Tafsir Tematik Islam Rahmatan Lil'Alamin. Jakarta: Pustaka Oasis. 2010.

Qodir, Zuly. dalam Fikih Kebinekaan Pandangan Islam Indonesia tentang Umat, Kewargaan, dan Kepemimpinan Non-Muslim. Bandung: Mizan. 2015.

Rahardjo, Dawam. Merayakan Kebebasan Beragama: Bunga Rampai Menyambut 70 Tahun Djohan Effendi. Jakarta: Democracy Project. 2011. 
Rajafi, Ahmad. Nalar Fiqh Muhammad Quraish Shihab. Yogyakarta: Istana Publishing. 2015.

Shihab, M. Quraish. Membumikan al-Qur'an; Fungsi dan Peran Wahyu dalam Kehidupan Mayrakat. Bandung: Mizan. 2009. . Mukjizat Al-Qur'an: Ditinjau dari Aspek Kebahasaan, Isyarat Ilmiah dan Pemberitaan Gaib. Bandung: Mizan. 2013. . Kaidah Tafsir: Syarat, Ketentuan, dan Aturan yang Patut Anda Ketahui dalam Memahami Ayat-Ayat al-Qur'an. Tanggerang: Lentera Hati. 2013.

sujanto, Bedjo. Pemahaman Kembali Makna Bhinneka Tunggal Ika. Jakarta: Sagung Seto. 2009.

Tafsir, M. Dalam Fikih Kebinekaan Pandangan Islam Indonesia tentang Umat, Kewargaan, dan Kepemimpinan Non-Muslim. Bandung: Mizan. 2015.

Yaqub, Ali Mustafa. Nikah Beda Agama dalam Al-Qur'an \& Hadis. Jakarta: Pustaka Firdaus. 2015.

Yunanto, Sri. Islam Moderat VS Islam Radikal: Dinamika Politik Islam Kontemporer. Yogyakarta: Media Pressindo. 2018.45 


\section{Endnotes}

1. Hikmah: ialah perkataan yang tegas dan benar yang dapat membedakan antara yang hak dengan yang bathil. Lihat, Achmad Fahrudin, dkk. AlQur'an Digital Versi 2.1, (T.t.t. Agustus ,2004). Hikmah juga diartikan dengan kata lain yaitu Allah SWT. menyuruh Rasulullah SAW. agar mengajak makhluk kepada Allah dengan hikmah, yakni dengan berbagai larangan dan perintah yang terdapat di dalam Al-Qur'an dan Sunnah, agar mereka waspada terhadap siksa Allah, Lihat, Muhammad Nasib Ar-Rifa'i, Ringkasan Tafsir Ibnu Katsir, (Jakarta: Gema Insani, 2000), Juz. II, Cet. II, h. 178.

2. Zuhairi Misrawi, Al-Qur'an Kitab Toleransi: Tafsir Tematik Islam Rahmatan Lil'Alamin, (Jakarta: Pustaka Oasis, 2010), h. 232.

3. Ahmad Rajafi, Nalar Figh Muhammad Quraish Shihab, (Yogyakarta: Istana Publishing, 2015), h. 47-48.

4. Ahmad Rajafi, Nalar Figh Muhammad Quraish Shihab, (Yogyakarta: Istana Publishing, 2015), h. 48-49.

5. M. Quraish Shihab, Mukjizat Al-Qur'an: Ditinjau dari Aspek Kebahasaan, Isyarat Ilmiah dan Pemberitaan Gaib (Bandung: Mizan, 2013), hlm. 297 Lihat juga M. Quraish Shihab, Secercah Cahaya Ilahi Hidup Bersama Al-Qur'an, (Bandung: Mizan, 2013), h. 5-6.

6. Islah Gusmian, Khazanah Tafsir Indonesia dari Hermeneutika hingga Ideologi, (Jakarta: Teraju, 2003), h. 82.

7. Howard M. Federspiel, Kajian Al-Qur'an di Indonesia; dari Muhammad Yunus hingga Quraish Shihab, terj. Tajul Arifin, (Bandung: Mizan, 1996), h. 295-296.

8. Faisal Isma'il, Republik Bhinneka Tunggal Ika, (Jakarta: Badan Litbang dan Diklat Kementrian Agama, 2012), h. 33.

9. Pembakaran gereja ini disinggung oleh BJ. Boland dalam bukunya The Struggle of Islam in Modern Indonesia yang dikutip oleh Azyumardi Azra dalam tulisan “Toleransi Agama dalam Masyarakat Majemuk: Perspektif 
Muslim Indonesia". Disebutkan juga bahwa pembakaran gereja ini terjadi di beberapa daerah yaitu Jawa Tengah dan Aceh. Lihat: Dawam Rahardjo, Merayakan Kebebasan Beragama: Bunga Rampai Menyambut 70 Tahun Djohan Effendi, (Jakarta: Democracy Project, 2011), h. 24.

10. Kasus ini terjadi pada bulan November 1998 sejumlah gereja dan bangunanbangunan lain dirusak oleh umat muslim. Lihat: Sufa'at Mansur, Toleransi dalam Agama Islam, h. 7.

11. Adapun salah satu ayat al-Qur'an yang menunjukkan bahwasanya Allah sangatlah mudah melakukan segala sesuatu ialah terdapat dalam firmanNya pada Q.S. Al-Nahl [16]: 40.

12. Irwan Masduqi, Berislam Secara Toleran: Teologi Kerukunan Umat Beragama, (Bandung: Mizan, 2011), h. 23-24.

13. Ahmad Syafii Maarif dalam Fikih Kebinekaan Pandangan Islam Indonesia tentang Umat, Kewargaan, dan Kepemimpinan Non-Muslim, (Bandung: Mizan, 2015), h. 27.

14. M. Tafsir dalam Fikih Kebinekaan Pandangan Islam Indonesia tentang Umat, Kewargaan, dan Kepemimpinan Non-Muslim, (Bandung: Mizan, 2015), h. 200201.

15. Fakhr al-Din al-Razi, Mafātih al-Ghaib, CD ROM Al-Maktabah As-Syamilah Versi 3.48, (Beirut: Dar Ihya' at-Turats, 1999), Jilid 7, h. 15.

16. Muhammad Nawawi al-Jawi, Marāh Labīd, (Beirut: Dar al-Kutub alIlmiyah,1997), Jilid I, h. 94.

17. Keberatan Ali Mustafa Yaqub terhadap pluralisme agama dapat dilihat dengan pernyataannya bahwa ada masa Nabi Saw. tidak ada pluralisme agama. Pluralisme adalah suatu paham yang mengajarkan bahwa kebenaran agama-agama itu relatif. Masing-masing agama tidak boleh mengklaim bahwa ajarannya saja yang benar, karena kebenaran mutlak adalah milik Tuhan. Islam tidak mengajarkan pluralisme, Islam hanya mengakui adanya pluralitas agama, bukan pluralisme, ia juga menukil dua ayat al-Qur'an sebagai landasan pernyataan tersebut, yaitu terdapat pada Q.S. Âli 'Imran [3]: 19 dan 85. Lihat, Ali Mustafa Yaqub, Nikah Beda Agama dalam AlQur'an \& Hadis, (Jakarta: Pustaka Firdaus, 2015), h. 54-55. 
18. Zuly Qodir dalam Fikih Kebinekaan Pandangan Islam Indonesia tentang Umat, Kewargaan, dan Kepemimpinan Non-Muslim, (Bandung: Mizan, 2015), h. 188189.

19. Zuly Qodir dalam Fikih Kebinekaan Pandangan Islam Indonesia tentang Umat, Kewargaan, dan Kepemimpinan Non-Muslim, (Bandung: Mizan, 2015), h. 189.

20. Ahmad Syafii Maarif, Islam dalam Bingkai Keindonesiaan dan Kemanusiaan: Sebuah Refleksi Sejarah, (Bandung: Mizan, 2009), h. 30-31.

21. Zuhairi Misrawi, Al-Qur'an Kitab Toleransi: Tafsir Tematik Islam Rahmatan Lil'Alamin, (Jakarta: Pustaka Oasis, 2010), h. 238. 